International Journal of Instruction e-ISSN: 1308-1470 • www.e-iji.net

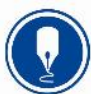

October $2018 \bullet$ Vol.11, No.4

p-ISSN: 1694-609X

pp. $825-840$

Received: 09/04/2018

Revision: 22/07/2018

Accepted: 28/07/2018

\title{
Teachers' Perceptions about the Relationship between 21st Century Skills and Managing Constructivist Learning Environments
}

\author{
Şengül S. Anagün
}

Assoc. Prof., Eskişehir Osmangazi Üniversitesi, Eskişehir, Turkey, ssanagun@ogu.edu.tr

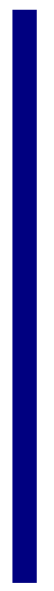

The purpose of this study is to examine the associations between the perceptions of primary school teachers about their proficiencies in terms of 21st century skills and their perceptions in relation to managing constructivist learning environments by means of structural equation modeling (SEM). The sample of the study included the classroom teachers from the province of Eskişehir. One hundred eighty-four females and 88 male teacher participated to the study. 21st century skills scale and TCLES were used to derive teacher perceptions regarding their proficiencies in 21 st century skills and their use of constructivist approaches in the classrooms. The results revealed that 21 st century skills were positively related to teachers' perceptions of the constructivist learning environment. Based on these results, a simple implication could be that when the teachers possess strong perceptions in relation to problem solving, critical thinking, cooperation, communication and creativity, they may appear to provide their students with learning environments that are more open to students' inquiry and investigation and that are thus more conducive to positive student attitudes.

Keywords: 21st century skills, constructivism, learning environment, SEM, classroom teachers

\section{INTRODUCTION}

There has been a recent emphasis on improving the quality of education over the past decade. In this trend, a fierce debate is taking place about the most important knowledge and skills of $21^{\text {st }}$ century. Global education reform movements goal is preparing students to solve complex problems associated with living in a competitive, technology-intensive world. Twenty-first century learners are digital learners and independent thinkers. They are absorbing the world around themselves by digital computing devices including the cellular phones, iPads, computers and gaming consoles (Palfrey \& Gasser, 2008). They have an almost instant access all around the world, communicating with a click of a button (Perry \& Stallworth, 2013). These students also have high expectations for speediness (Lemley et al., 2014) and access to information. In order to manage the realities of $21^{\text {st }}$ century, learners require education systems to change their practices. It is 
clear that the goals of education can no longer simply provide basic literacy skills for the students. Education systems should provide higher order thinking skills and competencies for all students. For these reasons, education systems should integrate " $21^{\text {st }}$ century skills" into the core curriculum. School systems have to enable students to develop the knowledge, skills and characteristics that will lead them to become personally successfull, economically productive, and activelly engaged citizens.

Although researchers and educators have come up with many definitions of the $21^{\text {st }}$ century skills, they generally refer to skills required by the learners in order to cope up with the realities and conditions of the $21^{\text {st }}$ century that are different from the previous century in terms of its focus on technology, digital work and more generally on the meaning and application of knowledge. That is, $21^{\text {st }}$ century skills encompass such basic skills as critical thinking, problem solving, creativity, communication, collaboration, innovation, teamwork, decision making, leadership, knowledge application, selfdirection and learning how to learn (Partnership for $21^{\text {st }}$ Century Skills, 2009; Organization of Economic Cooperation and Development, 2005; Larson \& Miller, 2011).

The framework created by Partnership for $21^{\text {st }}$ century skills $(\mathrm{P} 21,2009)$ has been more widely adopted because of its thematic relevancy for the $21^{\text {st }}$ century and well-structured design. In this framework, $21^{\text {st }}$ century skills are identified by three sets of skills: (1) learning and innovation, (2) life and career skills, and (3) information, media and technology skills. The P21 framework defines each skill set with specific key capabilities. Learning and innovation skills consist of competencies for engaging in critical thinking and problem solving, communicating, collaborating, and being creative and innovative. These skills focus on creativity, critical thinking, communication and coolaboration which are widely known as the 4Cs and these are essential to prepare students for a more complex life and work environments. Digital literacies cover the following three components: information, media and technology. Information literacy (IL) has been defined as being "able to recognize when information is needed and having the ability to locate, evaluate, and effectively use the needed information" (American Library Association,1989, p. 1). Media literacy (ML) refers to the ability to decode, evaluate, analyze, and produce print and electronic media (Aufderheide, 1997). Technology literacy points to the ability to use digital technology, communication tools, and/or networks to access, manage, integrate, evaluate and create information (International ICT Literacy Panel, 2002). Effective citizens and workers of the $21^{\text {st }}$ century must be able to represent a range of skills related to information, media and technology (P21, 2015). Life and career skills include capabilities to be flexible and adaptable, have a self-direction, engage in social and cross-cultural interactions, be productive and accountable, and have the potential to manage leadership and responsibilities.

The skills defined above are necessary to ensure the student mastery of $21^{\text {st }}$ century. Curriculum, instruction and learning environments must be aligned to produce a support system that will lead to the $21^{\text {st }}$ century outcomes for today's students. Twenty-first century skills are often generic and tacit in nature and they require distributed learning 
(Bransford et al., 2000; Sawyer, 2006). Their development may require an orchestrated and coherent learning environment at curricular levels (Lee et al., 2013)

\section{Teachers Role on $21^{\text {st }}$ Century Skills and Designing Constructivist Learning Environments}

Holland (1997) claimed that the environments foster the development of competencies, motivate people to engage in different activities, and reward people for their display of values and attitudes. Environment thus influences personal and professional self perceptions, competencies, attitudes, skills, and values. Constructivism is a popular approach at designing learning environments. Constructivism is a view of learning that students actively construct knowledge and learn based on their interaction with their environments. In constructivist approach, learning is taking place not because of the transference of knowledge from teacher to student via text or a personal knowledge base, but because the students interpret and make sense of their surroundings. In this context the teacher's role is to facilitate activities that will guide the learner into developing meaningful concepts (Peters \& Stout 2006). Therefore, the design of learning environment is one of the most important factors to support the constructivist learning. Creating an effective learning environment has become one of the teachers' challenges in helping students engage in and take responsibility for their own learning (National Research Council, 1996). Teachers are key actors who shape students' learning and have a critical role in implementing new approaches to learning. Leithwood et al (2009) confirm that teachers are important school-based factors in impacting student achievement. Hence, the development of education reforms relies heavily on teacher's capacity, perspective, motivation, commitment and their belief systems. Teacher belief systems are the most important factor to adopt constructivist practices (Levin \& Nevo, 2009). Beliefs and behaviors work collaboratively (Levitt, 2002) and beliefs have a powerful effect on teacher's classroom practices (Fullan, 2011). As teachers' epistemological beliefs guide their instructional and curricular decision making and their desire to adopt new pedagogies, opportunities to challenge and realign beliefs are critical if constructivist practices are to be adopted (Brand \& Moore, 2011).

A constructivist approach to teaching $21^{\text {st }}$ century skills involves new roles and demands on teachers. Teachers should understand the goals of constructivist curriculum, the students in their classrooms, and how to structure the learning environment to meet their needs. The most important way to improve productivity in educational environments based on constructivist approach is to take teachers' personal beliefs and values into account. Since the teacher is a critical component in the teaching and learning processes, identifying teacher perceptions about their own learning environment is necessary to implement the tenets of the constructivist reform movement in the classrooms. Thus, the purpose of this study is to examine the associations between the perceptions of primary school teachers about their proficiencies in terms of $21^{\text {st }}$ century skills and their perceptions in relation to managing constructivist learning environments by using structural equation model. 


\section{METHOD}

This study was conducted by means of structural equation modeling (SEM) which aims at examining the set of relationships within a set of interacting variables (Nokelainen, 2007). SEM is a comprehensive statistical approach used to test the models in which there are casual (represented with single-headed arrows) and correlational relationships (represented with bi-directional arrows) between clear (observed and measured) and latent (unobserved and unmeasured) variables (Hoyle, 1995). Taking a confirmatory rather than an exploratory approach, SEM introduces the details of the possible relationships among variables (Suhr, 1999). For parameters prediction and determination of model significance in the analysis of structural equation models, the following steps suggested by Eroğlu (2003) were adopted: (1) developing a theoretical model, (2) drawing a path diagram showing the casual relationships for the model developed, (3) transforming the diagram drawn into structural and measurement models, (4) predicting and assessing the structural model, (5) computing the eligibility criteria for the structural model and lastly (6) interpreting the results.

\section{The Sample}

The sample of the study included the classroom teachers from the province of Eskişehir. These participant teachers were conveniently sampled from seven primary schools located in Eskişehir. The data were screened for missing values and outliers, and the analyses were performed on the final sample of 233 teachers (184 females and 88 male teacher).

\section{Data Collection Instruments}

\section{$\underline{21^{\text {st }} \text { century skills scale }}$}

The original scale developed by Anagün et al (2016) aimed to measure teacher candidates' perceptions about $21^{\text {st }}$ century skills. Following the main stages of instrument development (review of literature, composition of the item pool, seeking expert opinions on the draft form of the scale, pilot study and determination of the construct validity), the final form of the $21^{\text {st }}$ century skills was developed. For the analysis of construct validity, the data from a sample of 233 teachers were first subjected to explanatory factor analysis (EFA) and that from another sample of 233 teachers were then subjected to confirmatory factor analysis (CFA). As a result of the exploratory factor analysis, 42 items remained on the draft scale and these items were collected under three factors named as learning and innovation skills, life and career skills, and information, media, and technology skills. Confirmatory factor analysis on the $21^{\text {st }}$ century skills competency scale conmfirmed the factor structure of 42 items, and this model was found to be theoretically and statistically valid. Accordingly, the validity and reliability analyses on the $21^{\text {st }}$ Century skills scale developed for the prospective teachers showed that the scale had sufficient psychometric properties. The same scale was adminstered to the teachers in this study and Cronbach Alpha coefficient was found to be .78 on the total scale, which means that the instrument revealed good and acceptable internal consistency relability with the sample of the study (Spector, 1992; Kline, 1999). 


\section{The Constructivist Learning Environment Scale- Teacher Form (TCLES)}

CLES as an instrument assessing students and teachers' perceptions about their learning environments. TCLES was developed to better enable teachers and researchers to determine teacher perceptions regarding the use of constructivist approaches in the classrooms. As evidenced by its widespread implementation and established validity in various countries, the CLES teacher form was selected for use in this study with its further ability to characterize specific dimensions of the constructivist classroom. TCLES is a valuable tool for assisting researchers and teachers in assessing the degree to which a classroom's environment is consistent with a constructivist epistemology, as well as for assisting teachers in reflecting on their epistemological assumptions and reshaping their practices. Modifications were performed to make this instrument better suited to assess the teachers' viewpoints. The TCLES was adapted to Turkish by Anagün \& Anılan (2013). The validity and reliability analyses of the survey were performed on 449 teachers randomly selected from primary schools in Turkey. The validity of TCLES was examined by means of explanatory and confirmatory factor analyses while the internal consistency of the scales was sought through cronbach alpha coefficient. While the original instrument included 30 items, the results from the factor analyses revealed that the Turkish adaptation of the original survey resulted in six factors and 18 items with internal consistency reliabilities ranging from .50 to .78 which supported the reliability of the instrument.

\section{Procedure}

The data for this study have been elicited from the teachers included in the sample by means of the data collection instruments utilized. Prior to data analysis, the following procedures were performed:

(i) The relationship between the primary school teachers' perceptions regarding $21^{\text {st }}$ century skills and their perceptions of constructivist learning emvironment was investigated using Pearson product-moment correlation coefficient. SPSS was used for the analyes of correlations.

(ii) The relationship between the primary school teachers' perceptions regarding $21^{\text {st }}$ century skills and their management of constructivist learning emvironment was investigated using Path Analysis based on structural equation modelling that is a type of multivariate statistics. The results from the factors of $21^{\text {st }}$ century skills were identified as an exogenous variable while those from the factors of constructivist learning environment treated as an endogenous variable. The independent variable ( $21^{\text {st }}$ century skills) have direct and indirect effects on the dependent variable (constructivist learning environment).

\section{Data Analysis}

Once data collection procedures and the composition of various data files were complete, a variety of analyses were completed. Confirmatory Factor Analysis (CFA) to operationalize the measures, goodness of fit indices for the measurement model, structural equation modeling (SEM), and fit statistics for the structural model to understand linkages among the latent variables using Linear Structural Relations 
(LISREL) were included in the analyses. Subsequently, a two-step LISREL (Jöreskog \& Sörbom, 1996) approach was used to further simplify and operationalize the measured variables used in developing the SEM and to generate goodness of fit statistics to determine the adequacy of the measurement and structural models. The descriptive statistics pertaining to the perceptions of proficiency in $21^{\text {st }}$ century skills and constructivist learning environment were presented seperately for each of sub-scales. Moreover, to see if the total means on the sub-scales significanly differs from the expected mean, one-samples t-test was conducted. As one samples t-test is a parametric test, Skewness and Kurtosis values were exaimed first to see if the scores on each of the sub-scales showed any violation of normality. Given the Skewness and Kurtosis for normality, the criterion that the obtained values are to be between -1 ve +1 was accepted. Thus, it was observed that the assumption of normality was violated for each sub-scale of the constructivist learning environment and these sub-scales were omitted from the one-sample t-test analysis mentioned above.

Following the above procedures, a measurement model was performed to investigate the associations between $21^{\text {st }}$ century skills and constructivist learning environment. Prior to the testing of the model, the data were examined for multivariate normality and it was found that the assumption of multivariate normality was violated for each of the scales included in the study $(\mathrm{p}<.05)$. Therefore, for rotation, robust maximum likelihood was prefered instead of the standard maximum likelihood technique.

\section{FINDINGS}

The results from the one-sample t-test conducted to see if the total means on the subscales significanly differs from the expected mean and those from the descriptives pertaining to the sub-categories of $21^{\text {st }}$ century skills and constructivist learning environment are presented in Table 1.

Table 1

The Results from Descriptives and One-sample t-tests

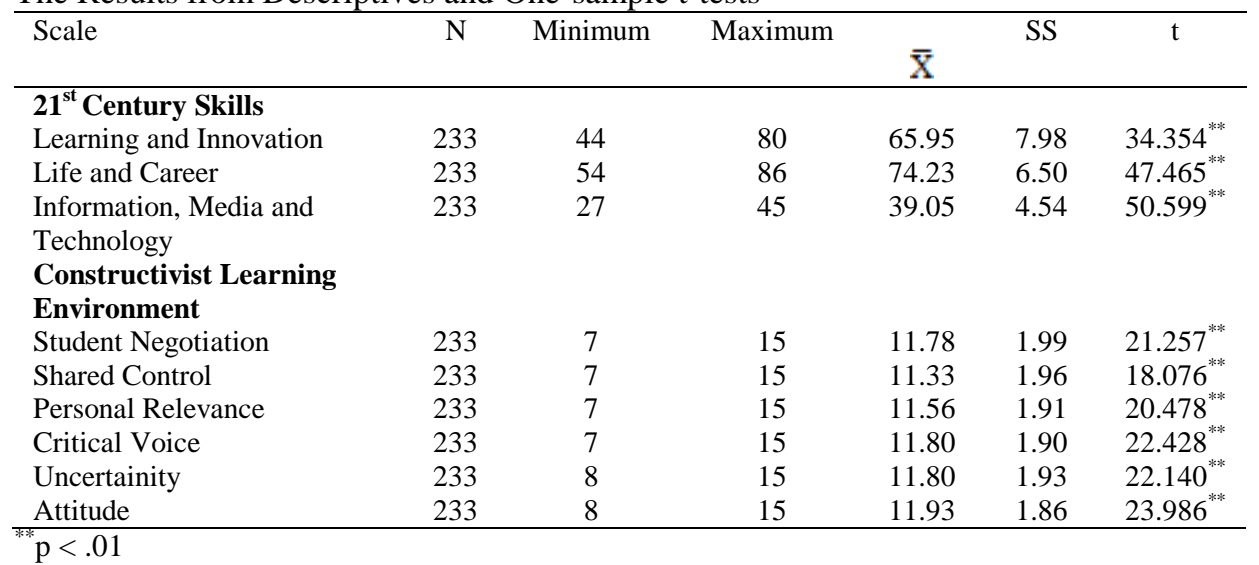


The results from the one-samples $t$ test indicated that the total means on the subcategories of $21^{\text {st }}$ century skills and constructivist learning environment significantly differed from the expected means $(\mathrm{p}<.01)$, which means that teachers' perceptions of managing constructivist learning environment are associated with their perceptions regarding their proficiencies in 21 st century skills.

A structural equation model was tested to investigate the associations between $21^{\text {st }}$ century skills and constructivist learning environment. Prior to this analysis, data were examined for the assumption of multivariate normality and it was seen that this assumption was violated $(\mathrm{p}<.05)$. Therefore, asymptotic covariance matrix was obtained and Robust maximum likelihood method was performed for the following analyses. Prior to the testing of the structural equation model, a confirmative factor analysis (CFA) was performed for each scale used in the study. Table 2 shows the fit indices from the CFA.

Table 2

The Fit Indices from the CFA of the Study Instruments

\begin{tabular}{lllllll}
\hline Dimension & $\chi^{2} / \mathrm{sd}$ & RMSEA & SRMR & CFI & GFI & AGFI \\
\hline Acceptable Values & $\leq 5$ & $\leq .080$ & $\leq .080$ & $\geq .90$ & $\geq .90$ & $\geq .90$ \\
$21^{\text {st }}$ Century Skills & 2.19 & .072 & .071 & .96 & .69 & .66 \\
Constructivist Learning Environment & 2.24 & .073 & .054 & .98 & .84 & .79 \\
\hline
\end{tabular}

In conclusion, it is seen that the factor structures proposed in the $21^{\text {st }}$ century skills scale and constructivist learning environment scale has been confirmed with the main data from this study. In this sence, the total scores from the three sub-dimensions of the $21^{\text {st }}$ century skills scale and those from the six sub-dimensions of the constructivist learning environment were used to test the measurement model proposed. In the model, the total scores from the sub-scales of the $21^{\text {st }}$ century skills and the constructivist learning environment were treated as observed variables. Accordingly, the tested measurement model is depicted in Figure 1. 


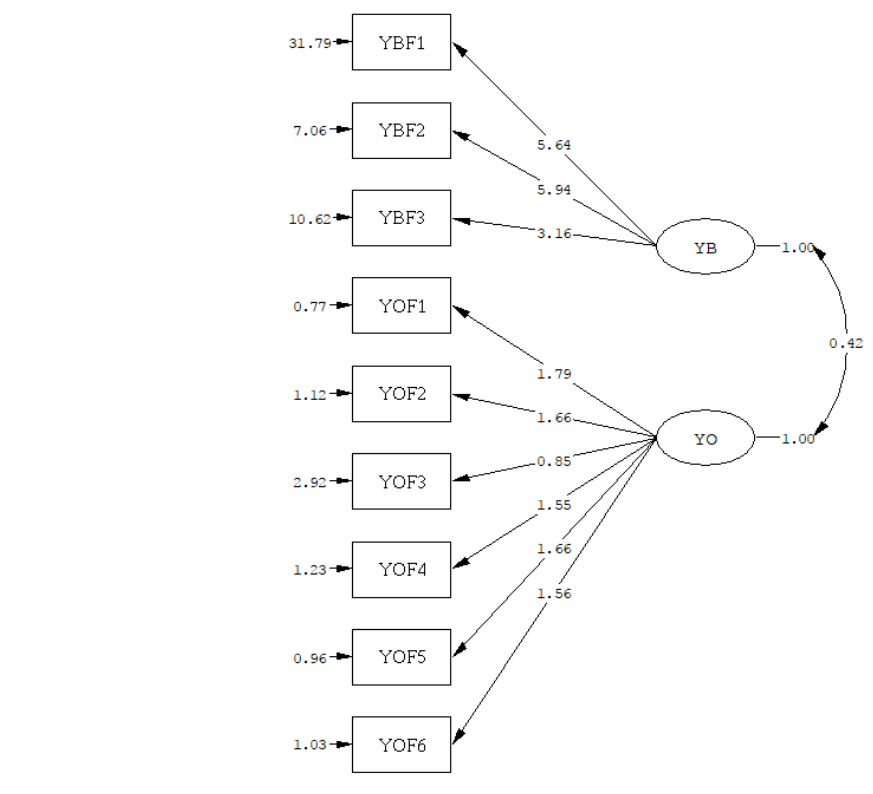

Chi-Square $=65.87, \mathrm{df}=26, \mathrm{P}-\mathrm{value}=0.00003, \mathrm{RMSEA}=0.081$

YBF1: Learning and Innovation, YBF2: Life and career, YBF3: Information, media and technology, YOF1: Student Negotiation, YOF2: Shared Control, YOF3: Personal Relevance, YOF4: Critical Voice, YOF5: Scientific uncertainity, YOF6: Attitude

Figure 1

SEM for $21^{\text {st }}$ century skills and constructivist learning environment (first round)

Given the interpretation of the measurement model, in this first round of testing, Root Mean Square Error of Approximation (RMSEA) and Adjusted Goodness of Fit Index (AGFI) revealed no good fit with their unacceptable values (Table 3).

Table 3

The Fit Indices from the Measurement Model (first round)

\begin{tabular}{lcccccc}
\hline Dimension & $\chi^{2} / \mathrm{sd}$ & RMSEA & SRMR & CFI & GFI & AGFI \\
\hline Acceptable Values & $\leq 5$ & $\leq .080$ & $\leq .080$ & $\geq .90$ & $\geq .90$ & $\geq .90$ \\
Model & 2.53 & .081 & .039 & .98 & .93 & .88 \\
\hline
\end{tabular}

When the modifications were sought, it was seen that the errors included in the subscales of critical voice and shared control could be associated with one another. Therefore, based on the assumption that all sub-scales converge to compose the main construct of constructivist learning environment, the errors pertaining to these sub-scales were also associated with one another and the model was tested again (i.e. the second round of testing). This retested measurement model is depicted in Figure 2 and relevant fit indices are shown in Table 4 below. 


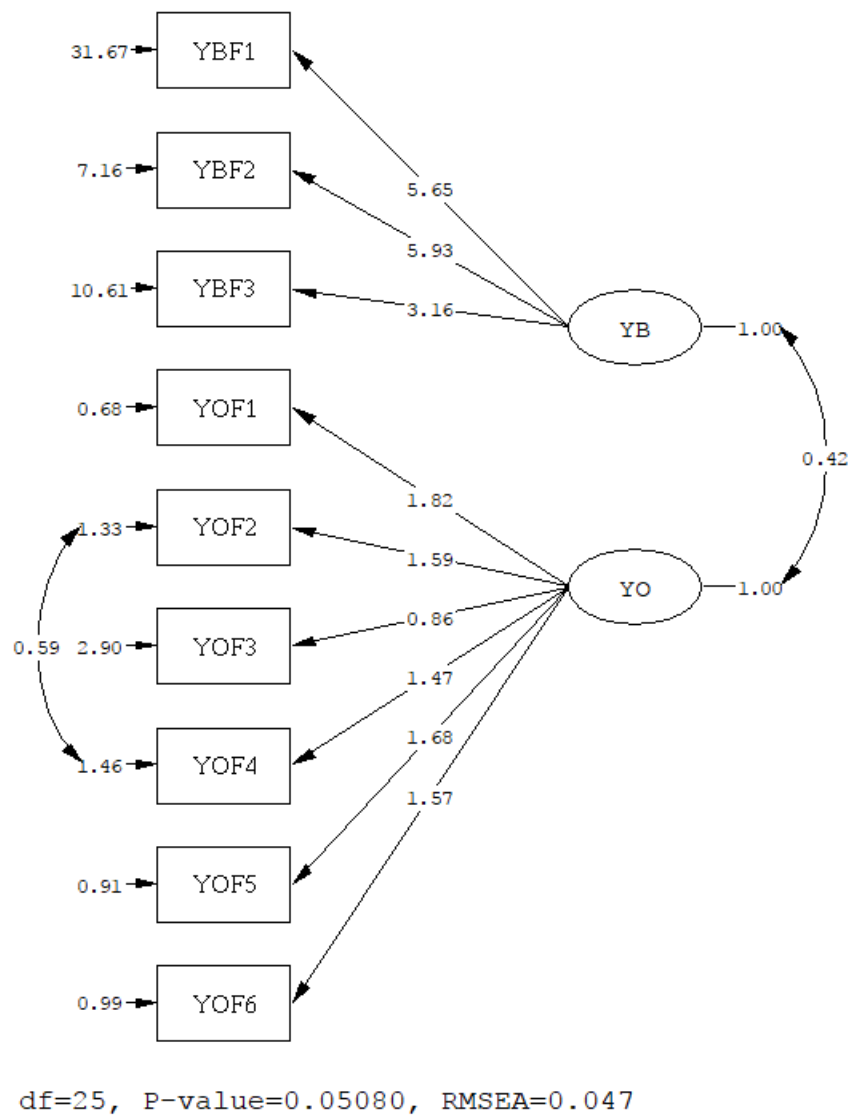

Figure 2

The mesurement model tested for $21^{\text {st }}$ century skills and constructivist learning environment (second round)

The results shown in Table 4 support a good fit of the variables to the measurement and structural models.

Table 4

Fit indices from the Measurement Model (second round)

\begin{tabular}{lllllll}
\hline Dimension & $\chi^{2} / \mathrm{sd}$ & RMSEA & SRMR & CFI & GFI & AGFI \\
\hline Acceptable Values & $\leq 5$ & $\leq .080$ & $\leq .080$ & $\geq .90$ & $\geq .90$ & $\geq .90$ \\
Model & 1.50 & .047 & .035 & .99 & .96 & .94 \\
\hline
\end{tabular}

The path coefficients from the measurement model are given in Table 5. 
Tablo 5

Path Coefficients from the Measurement Model

\begin{tabular}{lllll}
\hline Variables & $\begin{array}{l}\text { Standardized Factor } \\
\text { Coefficients }\end{array}$ & $\begin{array}{l}\text { Unstandardized } \\
\text { Factor Coefficients }\end{array}$ & SE & $\mathrm{t}$ \\
\hline $\mathbf{2 1}^{\text {st }}$ Century Skills & & & & \\
Learning and Innovation & 5.65 & .71 & .48 & $11.85^{* *}$ \\
Life and Career & 5.93 & .91 & .41 & $14.40^{* *}$ \\
Information, Media, and & 3.16 & .70 & .28 & $11.49^{* *}$ \\
Technology & & & & \\
Constructivist Learning & & & & \\
Environment & 1.82 & .91 & .09 & $21.43^{* *}$ \\
Student Negotiation & 1.59 & .81 & .10 & $16.26^{* *}$ \\
Shared Control & 0.86 & .45 & .12 & $6.97^{* *}$ \\
Personal Relevance & 1.47 & .77 & .10 & $14.58^{* *}$ \\
Critical Voice & 1.68 & .87 & .09 & $19.20^{* *}$ \\
Uncertanity & 1.57 & .84 & .09 & $17.80^{* *}$ \\
Attitude & & & &
\end{tabular}

* $\mathrm{p}<$

Given the $\mathrm{t}$ values in Table 5, all the paramers were significant, $\mathrm{p}<.01$. As the measurement model has fit the model, a structural equation model was tested by associating the perceptions of $21^{\text {st }}$ century skills and constructivist learning environment were associated with one another. Moreover, the above structural equation model reveals that student perceptions of Proficiency in $21^{\text {st }}$ century skills accounted for $18 \%$ of the variance in the perceptions of constructivist learning environment and the remaining $82 \%$ of the variance were explained by the other variables.

The relationship between the perceptions regarding $21^{\text {st }}$ century skills and the sub-scales of constructivist learning emvironment were examined by means of Pearson productmoment correlation coefficient and these coefficients were depicted in Table 6.

Table 6

The Relationship between the Perceptions of $21^{\text {st }}$ Century Skills and the Sub-scales of Constructivist Learning Emvironment

\begin{tabular}{llll}
\hline & $\begin{array}{l}\text { Learning and } \\
\text { Innovation }\end{array}$ & Life and Career & $\begin{array}{l}\text { Information, Media, and } \\
\text { Technology }\end{array}$ \\
\hline Student Negotiation & $.338^{* *}$ & $.348^{* *}$ & $.239^{* *}$ \\
Shared Control & $.251^{* *}$ & $.303^{* *}$ & $.228^{* *}$ \\
Personal Relevance & $.134^{* *}$ & .121 & $.177^{* *}$ \\
Critical Voice & $.273^{* *}$ & $.333^{* *}$ & $.256^{* *}$ \\
Uncertanity & $.374^{* *}$ & $.327^{* *}$ & $.235^{* *}$ \\
Attitude & $.324^{* *}$ & $.301^{* *}$ & $.232^{* *}$ \\
\hline
\end{tabular}

$$
* \mathrm{p}<.05 ; * * \mathrm{p}<.01
$$

When the correlation coefficients between the perceptions of proficiency in $21^{\text {st }}$ century skills and the sub-scales of constructivist learning emvironment were examined, it was seen that there was a moderate significant relationship between the perceptions of proficiency in $21^{\text {st }}$ centrury skills and the sub-scales of the constructivist learning environment with the exclusion of personal relevance sub-scale. 


\section{DISCUSSION}

This study was conducted to investigate the relationship between the primary school teachers' perceptions regarding $21^{\text {st }}$ century skills and their management of constructivist learning emvironment and it was found that $21^{\text {st }}$ century skills were positively related to teachers' perceptions of the constructivist learning environment. The results revealed a strong relationship between the learning and innovation sub-scale of the $21^{\text {st }}$ century skills and scientific uncertainity, student negotiation and attitude subscales of the constructivist learning environment. Based on these results the implication could be that when the teachers possess strong perceptions in relation to problem solving, critical thinking, cooperation, communication and creativity, they may appear to provide their students with learning environments that are more open to students' inquiry and investigation and that are thus more conducive to positive student attitudes.

A constructivist learning environment is the environment where knowledge is constructed by the students themselves (Brumbaugh \& Rock, 2006) and the teachers respecting this above claim in their teaching have their students feel themselves respectful and important. Teachers play an important role in helping students gain the $21^{\text {st }}$ century skills as an important component of today's education system. Therefore, teachers themselves should be able to design, apply and evaluate creative ideas, provide learning experiences that will attract students and enhance their learning, enrich their professional experiences and represent good role models as the teachers of the $21^{\text {st }}$ century (Karakaş, 2015).

The results of this study could only provide the degree to which the two main constructs, $21^{\text {st }}$ century skills and constructivist learning environment perceptions are associated with one another as reported by the teachers given the correlational design utilized in the study. Hence, it would be impossible to offer any causal associations or cause-effect relationships. In other words, the above results pertaining to the existence of a link between the teachers' perceptions about their proficiencies in terms of $21^{\text {st }}$ century skills and their capability of managing constructivist learning environments may not provide evidence for their real applications or real behaviors in the classrooms. Saydam (2009), for instance, claimed that though teachers hold positive beliefs towards constructivist approach, they could only partly perform it in their classrooms. Similarly, Anagün et al (2012) reported that teachers are unable to put their positive attitudes towards constructivist approach into practice when it comes to real classroom situations. Therefore, further studies should investigate the teachers'actual performance and find effective ways to develop teachers' constructivist teaching practices.

The results indicated positive associations between the two main constructs investigated in the study with an exception of those between life and career skills dimension of the $21^{\text {st }}$ century skills and scientific uncertainity sub-dimension of the constructivist learning environment. Thus, it could be implied that primary schools' teachers' holding positive perceptions in relation to entrepreneurship, leadership, responsibility and social and intercultural skills may result in their holding more positive perceptions related to almost all dimensions of a constructivist learning environment. The lack of an association between life and career skills and scientific uncertainity dimension may 
derive from the fact that teaching careers or furher professional lives of the teachers is more related to the social aspects of constructivist learning environment rather than a pure science content. In contrast to the presence of strong links between managing a constructivist learning environment and profiencies in $21^{\text {st }}$ century skills found in this study, some studies conducted in Turkey have reported that teachers experienced some difficulties in managing constructivist learning environments. For instance, Mutlu \& Güler (2017) reported that teachers faced difficulties in performing authentic instruction that is also based upon a constructivist approach in classroom practices and thus that would normally require the management of a constructivist learning environment by the teachers. The teachers included in Mutlu \& Güler's (2017) study faced problems in their managing authentic and constuctivist learning environment although the researchers included only those teachers who had already reported that they had been performing authentic instruction in their classrooms.

A further implication based upon the above account could be that though teachers have highly positive perceptions related to their proficiencies in $21^{\text {st }}$ century skills, they may experience difficulties in reflecting such perceptions into their practices. Supporting the above justification, the results from this study also revelaed that the associations between the teacher perceptions of the $21^{\text {st }}$ century skills and scientific uncertainity subdimension of the constructivist learning environment were lower when compared to those found at the moderate levels between $21^{\text {st }}$ century skills and all the remaining subdimensions of the constructivist learning environment. This smaller association on the part of the scientific uncertainity sub-dimension could stem from the fact that this dimension is more related to the teachers' actual management or control of the pedagocial tasks in the class and teachers of this study probably had difficulties in providing opportunities for students to experience scientific knowledge at the necessary levels. Moreover, it is a known fact that the effectiveness of the constructivist teaching and learning process is strongly dependent upon the teachers' attitudes (Saban, 2005), beliefs and in-class behaviors (Evrekli et al., 2009). Therefore, more detailed studies that would enable the researchers to investigate the degree to which the perceptions of the teachers' match with their actual performance in the classrooms. In this essence, participant observations of the teachers' classes could be performed to provide a more detailed picture of the research phenomenon investigated, which could also contribute to the triangulation of the data.

Another important result was the existence of weak or moderate associations over and beyond strong associations. This result may be due to the fact that some critical variables that might act as mediator or extraneous variables were not included as variables in the study. Several researchers (Dorman et al., 2006; Mutlu, 2017) also emphasized the importance of inclusion of these critical variables in linking several variables to learning environment perceptions. Therefore, worthy of further investigation would be the inclusion of some other variables such as teacher self-efficacy, teacher epistemological beliefs or some other teacher attitudinal variables when investigating the associations between the two main constructs in question for the purposes of this study. 
The results also revealed that there was a moderate relationship between the information, media and technology sub-scale of the $21^{\text {st }}$ century skills and all of the subscales of the constructivist learning environment, which would mean that when teachers feel themselves more capable of their $21^{\text {st }}$ century skills, they also feel themselves more capable of managing a constructivist learning environment. From this result, it might be inferred that if a teacher has information, media and technology skills, this teacher may easily manage a constructivist learning environment that would also require his/her ability to help the students construct information for their learning or learn how to construct information by means of locating, evaluating, analyzing, intergating and using the needed information, and as is expected this usually would require the use of digital or media techologies in today's modern life conditions (Kurt et.al, 2013).

Another result based on the descriptive statistics on the information, media and technology sub-scale pertains to the teachers' weak perceptions about their information, media and technology skills. In other words, it was seen that teachers included in this study perceived themselves less than moderate in terms of their competencies in information, media and technology skills. This result aligns with the results from the studies conducted on the project called The Movement to Enhance Opportunities and Improve Technology (shortened as FATİH in Turkish) started in 2010 in Turkey based on teacher perceptions. Several researchers from these studies (Altın \& Kalelioğlu, 2015; Çiftçi et al., 2013; Kurt et al., 2013; Pamuk et al., 2013) reported that teachers were lacking the necessary technological skills and they needed some practical and hands-on training to integrate technology in addition to the theory-based in-service training practices.

\section{CONCLUSION}

In this research, it was found that $21^{\text {st }}$ century skills were positively related to teachers' perceptions of managing constructivist learning environment. Thus, it could be inferred from the results of this study that when teachers possess positive perceptions about their proficiencies in terms of $21^{\text {st }}$ century skills, they may also make the neccessary arrangements in their classrooms so as to contribute to students' cognitive and affective outcomes. Another result from this study showed that each 21 centrury skill sub-scale excluding life and career skills positively related to each constructivist learning environment sub-scale except for the scientific uncertainity dimension. That is, when teachers possess positive perceptions about their proficiencies in $21^{\text {st }}$ century skills, they may provide a constructivist learning environment by helping their students arrange their own learning, discuss their personal opinions and criticize the teaching styles or strageies used by their teachers. However, teachers' possession of life and career skills as an aspect of $21^{\text {st }}$ century skills is not linked to their management of a constructivist environment where there is a certain degree of scientific uncertainity. The results also showed that most associations were at the weak or moderate levels pointing out the probable effects of some other variables that may influence the results. These influential variables could relate to teachers themselves or other contextual factors. The inclusion of such factors in the research design for further studies may bring about a broader picture of the research phenomenon investigated. Overall, with some minor exceptions 
on the subscales, this study connected teachers' peceptions regarding their proficiencies in 21 st century skills and their skills in managing a constructivist environment. Yet, further research is needed to test the presence of such connections and replicate the results with new samples and contexts.

\section{REFERENCES}

Altın, H. M. \& Kalelioğlu, F. (2015). Fatih Projesi ile ilgili Öğrenci ve Öğretmen Görüşleri. Başkent University Journal of Education, v 2 (1) 89-105.

American Library Association (1989). Presidental committee on information literacy:

Final report. Available at http://www.ala.org/ala/mgrps/divs/acrl/publications/whitepapers/ALA

Anagün, Ş. S.,Yalçınoğlu, P. \& Ersoy, A. (2012). Sınıf öğretmenlerinin Fen ve Teknoloji dersi öğretme-öğrenme sürecine ilişkin inançlarının yapılandırmacılık açısından incelenmesi, Kuramsal Ĕgitimbilim Dergisi, 5(1), 1-16.

Anagün, Ş. S. \& Anılan, H. (2013). Development and validation of a modified Turkish version of the Teacher Constructivist Learning Environment Survey (TCLES), Learning Environments Research, 16, 169-182.

Anagün, S. Ş., Atalay, N, Kılıç, Z. \& Yaşar, S. (2016). Öğretmen adaylarına yönelik 21. yüzyıl becerileri yeterlilik algıları ölçeğinin geliştirilmesi: Geçerlik ve güvenirlik çalışması. Pamukkale Üniversitesi Eğitim Fakültesi Dergisi, 40, 160-175.

Aufderheide, P. (1997). Media Literacy in the Information Age: Current Perspectives. Editor: Robert William Kubey.

Brand, B. R. \& Moore, S. J. (2011). Enhancing teachers' application of inquiry-based strategies using a constructivist sociocultural professional development model, International Journal of Science Education, 33(7), 889-913.

Bransford, J., Brophy, S. \& Williams, S. (2000). When Computer Technologies Meet the Learning Sciences: Issues and Opportunities, Journal of Applied Developmental Psychology 21(1): 59-84.

Brumbaugh, D. K. \& Rock, D. (2006). Teaching secondary mathematics, 3th ed. Hillsdale, NJ: Lawrence Erlbaum Associates.

Çiftçi, S., Taşkaya, S. M. \& Alemdar, M. (2013). The Opinions of Classroom Teachers About Fatih Project. Elementary Education Online, 227-240.

Dorman, J. P., Fisher, D. L. \& Waldrip, B. G. (2006). Classroom environment, students ${ }^{\text {ee }}$ perceptions of assessment, academic efficacy and attitude to science: A lisrel analysis. In D. Fisher \& M. S. Khine (Eds.). Contemporary approaches to research on learning environment: Worldviews (pp. 1-28). Australia: World Scientific.

Eroğlu, E. (2003), Toplam Kalite Yönetimi Uygulamalarının Yapısal Eşitlik Modeli ile Analizi (Yayımlanmamış doktora tezi). İstanbul Üniversitesi, Sosyal Bilimler Enstitüsü İşletme Anabilim Dalı, İstanbul. 
Evrekli, E., İnel, D., Balım, A. G. \& Kesercioğlu, T. (2009). Fen Öğretmen Adaylarının Yapılandırmacı Yaklaşıma Yönelik Tutumlarının İncelenmesi, Uludağ Üniversitesi Ĕgitim Fakültesi Dergisi, 12(2), 673-687.

FATİH. (2012). Eğitimde FATİH projesi hakkında. Retrieved March 5, 2017, from http://fatihprojesi.meb.gov.tr/proje-hakkinda/

Fullan, M. (2011). Change Leader: Learning to Do What Matters Most. San Francisco, CA: Jossey-Bass.

Holland, J. L. (1997). Making vocational choices: A theory of vocational personalities and work environments (3rd ed.). Odessa FL: Psychological Assessment Resources.

Hoyle, R.H. (1995). The Structural Equation Modeling Approach: Basic Concepts and Fundamental Issues In Structural Equation Modeling: Concepts, Issues and Applications, Sage Publications, USA. 289. 15p.

Jöreskog, K. G. \& D. Sörbom. (1993). LISREL 8: Structural Equation Modeling with the SIMPLIS Command Language. Chicago, IL: Scientific Software International.

Karakaş, M. M. (2015). Ortaokul sekizinci sinıf öğrencilerinin fen bilimlerine yönelik 21. Yüzyll beceri düzeylerinin ölçülmesi (Yayımlanmamış yüksek lisans tezi). Eskişehir Osmangazi Üniversitesi Eğitim Bilimleri Enstitüsü, Eskişehir.

Kline, P. (1999). The handbook of psychological testing ( $2^{\text {nd }}$ ed.) London: Routledge.

Kurt, A. A., Kuzu, A., Dursun, Ö. Ö., Güllüpınar, F. \& Gültekin, M. (2013). FATïH Projesinin Pilot Uygulama Sürecinin Değerlendirilmesi: Öğretmen Görüşleri. Journal of Instructional Technologies \&Teacher Education, 1(2).

Larson, L. C. \& Miller, T. N. (2011). 21st Century Skills: Prepare Students for the Future, Kappa Delta Pi Record, 47:3, 121-123.

Lee, J. C. K., Zhang, Z., Song, H. \& Huang, X. (2013). Effects of epistemological and pedagogical beliefs on the instructional practices of teachers: A Chinese perspective. Australian Journal of Teacher Education, 38(12), 120-146.

Leithwood, K., Mascall, B. \& Strauss,T. (2009). Distributed Leadership According to the Evidence, Routledge, London.

Lemley, J. B., Schumacher, G. \& Vesey, W. (2014). What learning environments best address $21^{\text {st }}$-century students' perceived needs at the secondary level of instruction? NASSP Bulletin, 98(2), 101-125.

Levin, T. \& Nevo, Y. (2009). Exploring teachers' views on learning and teaching in the context of a trans-disciplinary curriculum, Journal of Curriculum Studies, 41:4, 439465 .

Levitt, K. M. (2002). Teaching Culture as National and Transnational: A Response to Teachers' Work, Educational Researcher, 31(3), 19-21.

Mutlu, G. (2017). Linking EFL learning environment characteristics to persistence in 
EFL learning: A mixed-design study (Unpublished Doctoral Dissertation). Middle East Technical University, Ankara.

Mutlu, G. \& Güler, C. (2017). Authentic instruction: EFL teachers' perspectives. Paper presented at the European Conference on Educational Research (ECER 2017) of the European Educational Research Association, Denmark, Copenhagen. Retrieved from http://www.eera-ecer.de/ecer-programmes/conference/22/contribution/41901/

National Research Council. (1996). National science education standards. Washington, DC: National Academy Press.

Nokelainen, P. (2007). Introduction to Structural Equation Modeling, Research Centre for Vocational Education, University of Tempre, pp.1-34.

OECD (2006). Assessing Scientific, Reading and Mathematical Literacy: A Framework for PISA 2006, Paris: OECD Publications.

Palfrey, J., \& U. Gasser. (2008). Born digital: Understanding the first generation of Digital Natives. New York: Basic Books.

Pamuk, S., Ergun, M., Çakır, R., Yılmaz, H. B. ve Ayas, C. (2013). Öğretmen Ve Öğrenci Bakış Açısıyla Tablet Pc ve Etkileşimli Tahta Kullanımı: Fatih Projesi Değerlendirmesi. Kuram ve Uygulamada Eğitim Bilimleri. 13(3), 1799-1822.

Partnership for 21st Century Skills (2009). A framework for 21st century learning. Tucson: AZ: P21. Available at: www.21stcenturyskills.org

Partnership for 21st Century Skills (2015). Learning fort he 21st century.Washington DC:P21. Available at: www.21stcenturyskills.org

Perry, T. B. \& Stallworth, B. J. \& Lisa, F. (2013). 21st-century students demand a balanced, more inclusive canon, Voices from the Middle: Urban, 21(1), 15-18.

Peters, J. M. \& Stout, D. L. (2006). Methods for teaching elementary school science (5th ed.). Columbus, $\mathrm{OH}$ : Pearson Publishing.

Saban, A. (2005). Öğrenme-Öğretme Süreci, Ankara: PegemA Yayıncılık.

Sawyer, R. K. (2006). Educating for innovation, Thinking Skills and Creativity, 41-48.

Spector, P. E. (1992). Summated Rating Scale Construction: An Introduction. Newbury Park, CA: Sage.

Suhr, D. D. (1999). Investigation of Mathematics and Reading Achievement of 5through 14-Year Olds Using Latent Growth Curve Methodology $\mathrm{Ph} . \mathrm{D}$. Dissertation, Northern Colorado University. 